\title{
Bladder Neuroendocrine Carcinoma
}

National Cancer Institute

\section{Source}

National Cancer Institute. Bladder Neuroendocrine Carcinoma. NCI Thesaurus. Code C157759.

A malignant, high grade neuroendocrine neoplasm that arises from the bladder. This category includes small cell and large cell neuroendocrine carcinoma. 